на сложилось более лояльное отношение ко всем «убогим» вообще, нежели в западном католическом мире. В заключение, основываясь на теоретическом материале, изложенном в рамках данной работы, необходимо акцентировать тот факт, что феномен Христа ради свойствен исключительно русскому православию и, наряду с другими известными чертами самобытности, ещё раз свидетельствует об уникальности и самостоятельной типологичности русской культуры.
Список литературы

1. Жития святых на русском языке, изложенные по руководству Четьих-Миней святого Дмитрия Ростовского : в 12 т. Москва, 2005-2010.

2. Новый Завет Москва, 2014. 304 с.

3. Первое послание к коринфянам Святого апостола Павла // Апостол. Ярославль, 2009. C. $310-371$.

4. Нищще, Ф. Антихристианин // Сумерки богов. Москва, 1990. С. 17-93.

5. Достоевский, Ф. М. Братья Карамазовы. Москва, 1989. 336 с.

Olga N. Kuznetsova, Dr. of Art Criticism, Associate Professor, Altai State Institute of Culture (Barnaul, Russia) onk2007@mail.ru

\title{
WORLDVIEW FUNDAMENTAL PRINCIPLES OF FOOLISHNESS FOR CHRIST IN RUSSIAN ORTHODOX TRADITION
}

Abstract. The article outlines worldview senses of foolishness for Christ that is typical only for cultures of the greatest historical Orthodox states, Byzantium and Ancient Rus' (Russia). Foolishness for Christ is considered by the author as unique phenomenon of the Orthodox East that is a form of expression of basic Christian idea of self-abnegation, self-sacrifice that were commanded by the Jesus Christ Himself. The paper says about genesis of foolishness for Christ rooted from desert-dwellers' asceticism practices. Also, the analysis of artistic reflection of foolishness for Christ in Russian and world literature of various periods is given.

Keywords: foolishness for Christ, act of foolishness for Christ, Russian fools in Christ, worldview senses of foolishness for Christ, Orthodox Christianity, Catholicism, asceticism, self-abnegation, "eagerness for the Holy Cross", Kingdom of Heaven, heavenly world, earthy world, Fyodor Dostoevsky, "Karamazov Brothers", Grand Inquisitor, Church dissent.

\section{References}

1. ZHitiya svyatyh na russkom yazyke, izlozhennye po rukovodstvu CHet'ih-Minej svyatogo Dmitriya Rostovskogo [Lives of Saints in Russian Stated Under the Guidance of Saint Dimitry of Rostov' Menology]. 12 vol. Moscow, 2005-2010. [In Russ.].

2. Novyi Zavet [The New Testament]. Moscow, 2014. 304 p. [In Russ.].
3. Pervoe poslanie Svyatogo apostola Pavla $\mathrm{k}$ korinfyanam [The First Epistle of Paul the Apostol to the Corinthians]. Yaroslavl, 2009. Pp. 310-371. [In Russ.].

4. Nietzsche, F. Antihristianin [An Antichrist] // Sumerki bogov [Twilights of the Gods]. Moscow, 1990. Pp. 17-93.

5. Dostoevsky, F. M. Bratiya Karamazovy [Karamazov Brothers]. Moscow, 1989. 336 p.

УДК 316.74:[281.96+282](476)

DOI: $10.32340 / 2514-772 X-2019-1-40-49$

В. Р. Языкович, кандидат философских наук, доцент, Белорусский государственный университет культуры и искусств (Минск, Беларусь) yazykovich55@mail.ru

\section{ТРАДИЦИОННЫЕ РЕЛИГИИ И ЦЕРКВИ В СОВРЕМЕННОЙ БЕЛАРУСИ: МАСШТАБЫ ВЛИЯНИЯ, НАПРАВЛЕНИЯ ДЕЯТЕЛЬНОСТИ}

Аннотация. Представлены основные результаты ряда социологических исследований общегосударственного масштаба, посвящённых выяснению религиозной ситуации в современной Республике Беларусь. Приведены данные, характеризующие уровень вовлечённости граждан Беларуси в активную религиозную жизнь; перечислен состав наиболее влиятельных религиозных организаций в стране (лидирующие позиции здесь принадлежат Белорусской Православной Церкви, экзархату в составе Московского Патриархата). Представлен обзор основных направлений работы религиозных 
организаций Беларуси: духовное просвещение, информационная и культурная деятельность; перечислены крупные религиозно-образовательные, научные, художественные, музыкальные проекты и мероприятия, организуемые силами членов местных религиозных организаций. Подчёркнута ведущая роль православия в формировании нравственного сознания, культуры и искусства белорусского народа.

Ключевые слова: Белорусская Православная Церковь, Русская Православная Церковь, язык богослужения (литургии), духовно-просветительная работа, культурная деятельность, православная культура, религиозная идентичность, православие, католичество, ислам, иудаизм, межрелигиозныии диалог.

Приверженность традициям рассматривается как одна из определяющих ментальных черт национального характера белорусов. Поэтому возвращение к традиционным ценностям, восстановление влияния исторических религий, как правило, получает положительную оценку граждан Беларуси.

Результаты социологических и религиоведческих исследований последних лет показывают, что для жителей современной Беларуси характерен высокий уровень религиозной идентичности, при этом наблюдается ее существенный рост. Высокие показатели религиозной идентичности жителей Беларуси зафиксированы в ходе проведенного в 2012 году Информационно-аналитическим центром при Администрации Президента Республики Беларусь опроса населения страны, по результатам которого 95,5\% респондентов отнесли себя к той или иной религии. Из них: $83 \%$ составляют православные, 10\% - католики, 1,5\% другие религии $[1$, с. 44]. Важные качественные показатели были получены в ходе социологического исследования, проводившегося в 2012-2015 гг. Полученные результаты говорят о том, что для религиозного населения характерно устойчивое семейное положение $(50,3 \%$ респондентов состоят в браке, $28,1 \%$ респондентов никогда не состояли в браке (почти все они в возрасте до 30 лет), высокий уровень образованности (ок. $43 \%$ опрошенных имеют высшее образование, $32 \%$ среднее специальное), квалифицированная занятость (пенсионеры составили $30 \%$; специалисты $-15 \%$, студенты - $15 \%$, служащие $-8,5 \%$, руководители среднего звена $-5,6 \%$ ), умеренный уровень дохода (9,5 \% живут обеспеченно, 11,6\% выше среднего, 52,8 \% - скорее средне, ниже среднего - $22 \%$, скорее бедно $-4 \%$ ). Полученные данные позволяют характеризовать религиозное население Беларуси как социально стабильную среду. Религиозный выбор жителей Беларуси осуществляется преимущественно сознательно в рамках распространенных в обществе традиций. Исследователи делают вывод о том, что религия является для белорусов важным ценностно-мотивирующим фактором [2].

В целом конфессиональная карта современной Беларуси выглядит пестрой. По данным аппарата Уполномоченного по делам религий и национальностей Республики Беларусь (далее - РБ) на начало 2015 г. в стране было представлено 26 конфессий, зарегистрировано 3488 религиозных организаций, в т. ч. 3315 религиозных общин. Общая численность действующих культовых зданий составляет 2618 , строящихся -245 . По социологическим данным, из общего количества верующих только $5,5 \%$ регулярно принимают участие в исполнении религиозных обрядов. Изредка присутствуют на богослужении $37 \%$ верующих. Степень влияния религиозных традиций существенно отличается в восточной и западной части Беларуси. Более высоким является уровень религиозности в западных областях, где верующие составляют до 70-80 \% населения. Там же находится большая часть общин. Общий вывод, который делают специалисты, изучающие тенденции трансформации религиозных традиций в Беларуси, заключается в том, что «религия восстановилась и функционирует в культурном пространстве Беларуси в ответ на потребность, во-первых, восстановления исторической памяти и этно-культурной идентичности и, во-вторых, преодоления мировоззренческой и ценностной дезориентации в эпоху смены идеологических парадигм. Первое привело к увеличению числа приверженцев доминирующих и других традиционных для Беларуси религий, второе - к появлению новых для ее культурного поля исповеданий» [3, c. 105].

Наиболее влиятельным среди религиозных объединений в Республике Беларусь является Белорусская православная церковь (далее БПЦ), которая канонически подчинена Московскому патриархату. БПЦ возглавляет митрополит Минский и Заславский Павел (Пономарёв), патриарший экзарх всея Беларуси. По данным аппарата Уполномоченного по делам религий и национальностей РБ, БПЦ объеди- 
няет 1643 прихода, 15 епархий, 35 монастыря, 15 братств и 10 сестричеств, имеет 7 духовных учебных заведений. В РБ действуют 1535 православных храмов, еще 194 строятся. БПЦ осуществляет полномасштабную религиознолитургическую, пастырскую и духовноокормляющую деятельность. Ведется работа по канонизации белорусских святых. В 1999 г. были канонизированы 23 новомученика.

Белорусская Православная Церковь ведет значительную духовно-просветительную и информационную работу. Начиная с 2015 года, БПЦ проводит ежегодные Белорусские Рождественские Чтения. Издательскими службами БПЦ выпускается значительное количество периодических изданий, в т. ч. епархиальные ведомости. БПЦ имеет еженедельную радиопрограмму «Благовест». Священнослужители БПЦ ведут регулярные циклы передач на различных каналах национального телевидения.

В богослужение БПЦ постепенно вводится белорусский язык. На белорусском и русском языках ведется преподавание в учебных заведениях Церкви, изданы литургические тексты и Евангелие.

В столице Республике Беларусь работает Минская духовная академия (далее - МинДА). Начиная с 2001 года, МинДА ежегодно проводит Семинары студентов высших учебных заведений Беларуси, тематика которых посвящается выдающимся деятелям национальной культуры, литературы и философии, актуальным проблемам жизни общества и важным событиям культурной истории Беларуси. В г.п. Жировичи (Гродненская область) работает Минская духовная семинария имени Вселенских учителей и святителей Василия Великого, Григория Богослова и Иоанна Златоуста. В 2004 г. был открыт Институт теологии имени свв. Мефодия и Кирилла Белорусского государственного университета, который ведет подготовку светских кадров по специальности «Теология» на первой (бакалавриат) и второй (магистратура) ступенях высшего образования. Совместно с Белорусским государственный университетом культуры и искусств Институт теологии имени свв. Мефодия и Кирилла ежегодно проводит международные КириллоМефодиевские чтения, посвященные Дням славянской письменности и культуры.

Православное духовное наследие имеет особенное значение для развития белорусской культуры. Социально-гармонизирующий и духовный опыт православия стал судьбоносным для восточноевропейской культуры. Общеизвестно определяющее влияние правосла- вия на формирование менталитета, развитие нравственного сознания, художественной культуры, литературы и философии восточнославянских народов. Традиции цивилизованного образа жизни и государственности, книжности и образованности, интеллектуализма и социальной поддержки сложились на белорусских землях под базовым влиянием православия. Единое православное духовное, художественно-эстетическое и интеллектуальное наследие можно рассматривать в качестве важнейшей предпосылки активного сотрудничества братских народов Беларуси, России и Украины. При этом огромное значение приобретает межрелигиозное взаимопонимание и взаимодействие, активные межцерковные связи. Проблематика сотрудничества православных народов в социально-политической и духовной сферах нашла отражение в речах, выступлениях и трудах руководителей Русской Православной Церкви. Так, в своем Слове на встрече с руководством Республики Беларусь и Белорусской Православной Церкви 25 сентября 2009 г. Патриарх Московский и Всея Руси Кирилл отметил, что «год от года Православная Церковь по праву становится одним из важных институтов Белорусского общества, надежной опорой государства и народа. Ее действия по формированию нравственного облика гражданина, по духовному воспитанию общества находят отклик не только в сердцах простых верующих, но и у представителей власти, общественных организаций, институтов гражданского общества». Патриарх отметил, что национальное строительство в стране, подавляющее большинство населения которой исповедует православие, невозможно без активного участия Церкви, православная вера является одной из основ единения братских народов Беларуси, России и Украины. Предстоятель Русской Православной Церкви указал на то, что она всегда готова поддержать укрепление и развитие Союза братских государств и оказывать помощь в диалоге белорусского руководства с российскими властями и содействие в развитии диалога между общественными организациями Беларуси и России. Патриарх выделил такую область взаимного сотрудничества и обмена полезным опытом как религиозное образование, высоко оценил сложившуюся в Беларуси систему взаимоотношений государства с Церковью в образовательной сфере. По его мнению, для белорусской системы образования был бы интересен российский опыт преподавания основ религиозной культуры в средней школе. Была выра- 
жена надежда на тесное взаимодействие церковных представительств при международных организациях. В качестве актуальных областей сотрудничества в рамках деятельности международных организаций Патриарх Московский и Всея Руси выделил миротворчество, межкультурный и межрелигиозный диалог, права и свободы человека, духовно-нравственное воспитание, построение справедливого и процветающего общества. Предстоятель Русской Православной Церкви отметил, что восточнославянские страны представляют собой единую цивилизацию, в основе которой лежат общая православная вера и определяемая ею система ценностей. Верность этому наследию будет укреплять национальную и культурную самобытность восточнославянских народов, обеспечивать их реальный суверенитет. Патриарх выразил надежду, что духовная и культурная самобытность народов России, Украины, Беларуси и Молдовы помогут «иметь скоординированную и сильную позицию в диалоге с окружающим миром».

Второй по числу верующих в Беларуси является римско-католическая церковь (далее РКК) В созданную в 1999 г. Конференцию католических епископов (епископат) Беларуси вошли 4 епископа во главе с кардиналом Казимиром Свентаком. По данным аппарата Уполномоченного по делам религий и национальностей РБ католическая церковь в Беларуси объединяет 5 епархий, 491 приход, 11 миссий, 10 монастырей, 5 духовных учебных заведений. Общины католиков располагают 488 костелами, 36 костельных зданий строятся. Католическая церковь Беларуси непосредственно подчиняется Ватикану. Влияние польского костела сохраняется в настоящее время. Из Польши поступает литература, богослужение и делопроизводство часто ведется на польском языке. Из 376 священников, которые служат в католических приходах в Беларуси, 113 являются иностранными гражданами, в основном - Республики Польша. Богослужение в костелах Беларуси ведется преимущественно на белорусском языке, на нем издается основной массив религиозной литературы. Ведущим католическим высшим учебным заведением в РБ является Гродненская духовная семинария, работающая с 1990 г. и подготовившая за период с 1995 по 2008 гг. 161 священнослужителя. С 2002 г. действует Пинская высшая католическая духовная семинария имени св. Фомы Аквинского. В Беларуси зарегистрированы 2 традиционалистские общины католиков, которые придерживаются старого, дособорного учения. Католическая церковь Беларуси ведет активную духовнопросветительскую и образовательную деятельность, осуществляет значительные издательские программы. Руководством РКК и местными церковными властями организуется большое количество разнообразных мероприятий образовательной, художественной и спортивной направленности. Сегодня в костел активно привлекается молодежь, для которой проводятся богослужения с гитарным сопровождением, специальные паломничества, сборы.

Деятели католической церкви внесли существенный вклад в развитие белорусской культуры. Начиная с 1995 г. в костеле св. Роха и в костеле свв. Симона и Елены (Красный костел) (г. Минск) ежегодно проводится фестиваль духовной музыки «Золотая лира». Неотьемлемой частью культурной жизни Беларуси стал международный фестиваль духовной музыки «Магутны Божа», который, начиная с 1993 г., проводится в г. Могилеве, и имеет целью возрождение традиций христианской духовной музыки, объединения христиан разных конфессий. В фестивалях традиционно участвуют исполнители и творческие коллективы из стран ближнего зарубежья. Заметным является участие католической церкви в диалоге церквей и конфессий.

По данным 2015 г. в РБ зарегистрировано 13 греко-католических общин. Самая крупная из них находится в Минске. Преимущественный состав греко-католических общин составляют представители интеллигенции. В общинах Минска и Гродно имеются рукоположенные священники. В 1996 г. состоялись конференции, семинары и торжественные службы униатов, посвященные 400-летию Брестской церковной унии.

По данным аппарата Уполномоченного по делам религий и национальностей РБ протестантские религиозные организации представлены 1057 религиозными общинами, 21 объединением, 22 миссиями и 5 духовными учебными заведениями 14-ти направлений. В республике открыт 561 молитвенный дом, строится большое количество протестантских культовых зданий. Пресвитеров, проповедников и регентов готовят 2 высших и 2 средних учебных заведения. Протестантские объединения издают много журналов и газет. В 2003 г. протестантские организации торжественно отмечали 450летие Реформации в Беларуси. Юбилейная дата связывается с основанием первой кальвинистской общины на территории Беларуси.

Для протестантских объединений Белару- 
си характерны международные контакты. Союз евангельских христиан-баптистов (далее ЕХБ) в РБ входит в Евразийскую федерацию союзов ЕХБ СНГ. Для протестантских объединений Беларуси характерно активное участие в международных религиознохудожественных проектах. Например, Объединенная Церковь христиан веры евангельской в РБ занимается организацией региональных и международных музыкальных мероприятий.

Крупнейшими протестантскими направлениями в РБ являются евангельские христиане-баптисты (ЕХБ) и христиане веры евангельской (далее - ХВЕ), Союз евангельских христиан-баптистов в Беларуси представлен 312 общинами и почти 14 тыс. верующих. Существуют также автономные объединения ЕХБ и общины Совета церквей ЕХБ, которые осуществляют свою деятельность вне государственной регистрации. Согласно уставу, Союз ЕХБ в РБ является добровольным религиозным объединением церквей и региональных объединений, исповедующих вероучение ЕХБ. К задачам Союза относятся проповедование Евангелия, благотворительная деятельность, организация новых общин, миссий, учебных заведений и других организаций, издание и распространение Библии, духовной литературы, газет и журналов, аудио-, видео-, компьютерной и другой электронной и печатной продукции христианского содержания. Союз имеет право создавать региональные объединения, центры, учебные заведения, миссии, проводить богослужения, конференции и другие мероприятия. Высший орган управления Союза - съезд, который созывается каждые четыре года. Съезд принимает решения по отчетам епископа (председателя) и исполнительного секретаря Союза, избирает их, утверждает вероучение ЕХБ, принимает устав, рассматривает иные вопросы деятельности Союза. 17 марта 2018 г. прошел 16-й съезд Союза ЕХБ в РБ. В период между съездами деятельностью руководит Совет Союза ЕХБ в РБ, который проводит заседания по меpe необходимости, но не реже одного раза в квартал. Минская богословская семинария, открытая в 1997 г., является высшим духовным образовательным учреждением Союза ЕХБ в РБ. Обучение в семинарии осуществляется на 4 факультетах (богословском, музыкальном, педагогическом, факультете благовестия) и в библейском колледже. Среди областей Беларуси наибольшее количество общин ЕХБ находится в Брестской области. Одним из крупнейших в Европе является молитвенный дом ЕХБ в г. Кобрин, его вместимость составляет 1500 человек. Общины ЕХБ ведут активное социальное служение. В детском оздоровительном лагере в Кобринском районе, перешедшем в ведение Союза ЕХБ, на отдыхе побывало большое количество детей. При поддержке Союза ЕХБ белорусские дети ежегодно выезжают на оздоровление во многие страны мира.

Широкое распространение в современной Беларуси получили движения пятидесятнического и харизматического типа, для которых характерны призывы к внутреннему преображению, сильные эмоциональные проявления, отказ от сосредоточенности на повседневной жизни. Пятидесятнические направления, представленные в Беларуси, характеризуется значительным влиянием, динамикой и миссионерской активностью. Объединенная церковь христиан веры евангельской в РБ в 2015 г. была представлена 512 общинами. Количество членов Объединенной церкви XВE, принявших крещение, на начало 2012 г. оценивалось в 32 тыс. человек. В 2002 г. на базе Объединенной церкви действовало 330 воскресных школ, в которых обучалось 13304 ребенка. В структуру Союза ХВЕ входят два богословских учебных заведения, находящиеся в Минске, - теологический институт и библейский колледж «Христос для народов» (зарегистрированы в 1996 г.). Теологический институт готовит духовных работников: пасторов, проповедников, евангелистов, миссионеров, преподавателей богословских дисциплин для библейских институтов, колледжей, воскресных школ. Большинство изучаемых в институте предметов преподают иностранные граждане, имеющие ученые степени в области богословия. Получить духовное образование пятидесятники из Беларуси имеют возможность в московском Библейском колледже «Благодать» Объединенной церкви XBE России.

При общинах XBE создаются группы прославления и музыкальные коллективы. Объединенная церковь XВЕ занимается организацией музыкальных региональных и международных мероприятий. Минская организация «Христос для народов» выступила в числе организаторов ставшего ежегодным симпозиума Хвалы и Поклонения в Санкт-Петербурге, в котором принимают участие представители различных протестантских направлений.

Объединенная церковь ХВЕ в РБ проводит определенную социальную работу, имеются отделы социальной и душепопечитель- 
ской работы, учебно-методический центр воскресных школ, центр тюремного служения, центр социальной работы, центр реабилитационной работы, центры женского, молодежного и семейного служения. Верующие ведут социальную работу в тюрьмах, а также с людьми, страдающими от наркотической и алкогольной зависимости. В 1993 г. на базе Объединенной церкви XВЕ было официально организовано женское служение. Женский отдел при Объединенной церкви XВE 2-3 раза в год организует обучающие семинары для лидеров женского служения, педагогов и врачей, сотрудничает с медперсоналом учреждений здравоохранения. В рамках женского служения проходит движение усыновления, организуются детские дома семейного типа. 12 мая 2018 г. в Минской церкви «Благодать» прошел $\mathrm{X}$ съезд Объединенной Церкви ХВЕ в Республике Беларусь.

В РБ зарегистрированы другие протестантские объединения и общины: Белорусская конференция адвентистов седьмого дня (73 общины), религиозное объединение общин полного Евангелия (55 общин), 27 лютеранских общин, 10 общин евангельских христиан в духе апостольском, кальвинистская христианская религиозная конгрегация Белорусский евангелический реформаторский сбор (1 община). В РБ представлены религиозные направления неопротестантского толка: Новоапостольская церковь (21 община), Церковь Христова (5 общин), общины мессианского служения (2), Церкви Иисуса Христа святых последних дней (мормоны) (4 общины).

В РБ зарегистрированы 33 старообрядческие общины. 18 из них находятся в Витебской области. Старообрядчество представлено общинами поповцев, относящихся к белокриницкой церкви, и беспоповцев (федосеевского, поморского, филипповского согласий).

Исторически традиционной религией Беларуси является иудаизм. В современной Беларуси представлены ортодоксальное и прогрессивное направления иудаизма. В 2015 г. зарегистрировано 36 иудейских общин традиционного направления, крупнейшие из них в Минске, Могилеве и Бобруйске. В Минске действуют 2 высших духовных училища (ешибота). Зарегистрированы 17 общин прогрессивного иудаизма и 2 мессианские общины. За значительный исторический период своего бытования в Беларуси иудейские общины внесли значительный вклад в развитие культуры нашей страны. До начала Великой Отечественной войны половину городского населе- ния Беларуси составляли евреи. В 1920-ые гг. идиш был одним из 4 государственных языков БССР. Выходцами из Беларуси являются известные художники еврейского происхождения (Марк Шагал, Хаим Сутин, Леон Бакст и др.). С 2002 г. в Минске работает Музей истории и культуры евреев Беларуси.

Ислам представлен в Республике Беларусь 25 общинами мусульман-суннитов, 8 из которых находятся в Гродненской области. В 1994 г. на Первом Всебелорусском съезде мусульман в Минске было создано Мусульманское религиозное объединение (муфтият) Республики Беларусь. В настоящее время муфтием является Абу-Бекир Шабанович. В Республике Беларусь проводится работа по реставрации и восстановлению старых мечетей, также ведется строительство новых. Торжественное открытие Минской соборной мечети прошло 11 ноября 2016 г. с участием Президента Республики Беларусь А.Г. Лукашенко и Президента Турецкой Республики Реджепа Тайипа Эрдогана. Мусульманские общины в Республике Беларусь ведут культурно-просветительскую работу. Мусульмане, проживающие на территории Беларуси с XIV в., внесли существенный вклад в культурное развитии белорусского общества. Сохранились письменные памятники мусульманской культуры, среди которых особенное значение имеют китабы-книги, написанные арабскими буквами на белорусском языке. К памятникам мусульманской культуры в Беларуси относятся исторические здания мечетей и мизары (кладбища).

В Республике Беларусь была разработана современная нормативно-правовая база, регламентирующая положение и деятельность религиозных организаций. В Законе Республики Беларусь «О свободе вероисповедания и религиозных организациях» (1992 г.) нашли отражение новые социально-экономические и политические условия деятельности религиозных организаций. В правовой и общественно-политической системе Беларуси сформировались современные подходы к регулированию проблем свободы совести. Законодательство предусматривает равенство религий перед законом, право граждан свободно определять свое отношение к религии, единолично или совместно с другими исповедовать любую религию или не исповедовать никакой, выражать и распространять убеждения, связанные с отношением к религии. Государство не вмешивается в дела религиозных организаций, которые в свою очередь отказываются от участия в политической жизни. Эти подходы в 
отношении религиозных организаций были закреплены в Конституции Республики Беларусь 1994 года. В статье 16 утверждается равенство религий перед законом, отмечается, что взаимоотношения государства и религиозных организаций регулируются законом с учетом их влияния на формирование духовных, культурных и государственных традиций белорусского народа, запрещается деятельность религиозных организаций, их органов и представителей, направленная против суверенитета Республики Беларусь, ее конституционного строя и гражданского согласия, либо сопряженная с нарушением прав и свобод граждан, а также препятствующая исполнению гражданами их государственных, общественных, семейных обязанностей или наносящая вред их здоровью и нравственности.

В 2000-е гг. в общественном сознании сформировалось более глубокое понимание роли религии в развитии общества, ее влияния на культуру, нравственность, значение в современном обществе. С учетом произошедших изменений была разработана новая редакция закона, принятая в 2002 г. как Закон Республики Беларусь «О свободе совести и религиозных организациях». В преамбуле закона подтверждается право каждого на свободу совести и свободу вероисповедания, равенство перед законом независимо от отношения к религии, равенство религий перед законом, необходимость содействия достижению взаимопонимания, терпимости и уважения религиозных чувств граждан. Отмечается роль конфессий в историческом становлении белорусского народа, развитии его духовных, культурных и государственных традиций. Подчеркивается определяющая роль православной церкви в историческом развитии белорусского общества, духовная, культурная и историческая роль католической церкви на территории Беларуси, указано на неотделимость от общей истории белорусского народа евангелическолютеранской церкви, иудаизма и ислама. Действие законодательства о свободе совести и религиозных организациях распространяется на все религиозные структуры, независимо от степени их влияния и распространенности в настоящее время. Взаимоотношения государства с религиозными организациями строятся на основе исторического опыта, влияния конфессий на формирование духовных, культурных и государственных традиций белорусского народа. В законе отмечается, что государство может строить свои взаимоотношения с религиозными объединениями путем заключе- ния с ними соглашений в соответствии с гражданским законодательством РБ. Таким образом, при соблюдении принципа светскости, религиозные организации получают возможность конкретизировать формы своего взаимодействия с государством. Приоритеты государственной конфессиональной политики определены как «установление отношений терпимости и уважения между гражданами, исповедующими и не исповедующими религию, религиозными организациями различных вероисповеданий». На современном этапе государство не исходит из приоритета какой-либо идеологии, религиозного либо атеистического типа, руководствуется необходимостью поддержания гражданского согласия, стремится предотвратить возникновения межконфессиональных конфликтов.

Реализует государственную политику в области отношений с религиозными организациями государственный орган управления по делам религий и национальностей. На него возложены функции контроля за деятельностью религиозных организаций в части исполнения ими законодательства Республики Беларусь о свободе совести, вероисповедания и религиозных организациях, оказание содействия в достижении взаимопонимания между религиозными организациями различных вероисповеданий, назначение государственной религиоведческой экспертизы.

Законом устанавливается порядок регистрации религиозных организаций. Базовой формой религиозных организаций являются религиозные общины, которые образуются по инициативе не менее двадцати граждан Республики Беларусь и подлежат государственной регистрации. Религиозные общины регистрируются облисполкомами и Минским горисполкомом. Законом предусматривает возможность создания религиозных объединений, которые образуются при наличии не менее десяти религиозных общин единого вероисповедания, из которых хотя бы одна осуществляет свою деятельность на территории Республики Беларусь не менее двадцати лет. Религиозные объединения имеет свои органы управления. Республиканским признается религиозное объединение, образованное из религиозных общин, действующих в большинстве областей Республики Беларусь. Религиозные объединения имеют право создавать монастыри и монашеские общины, религиозные братства и сестричества, миссии, духовные учебные заведения, которые действуют на основе уставов. Религиозные объединения имеют право созда- 
вать средства массовой информации, приглашать иностранных граждан в целях занятия религиозной деятельностью в порядке, установленном законодательством Республики Беларусь. Законодательством определены имущественные права религиозных организаций, формы и условия их деятельности. Зарегистрированные религиозные организации имеют существенные налоговые льготы.

Государство занимает конструктивную позицию в отношении религиозных организаций, конфессиональная политика направлена на сохранение мира и стабильности в обществе, реализацию гражданами прав на свободу совести и вероисповедания.

Перед белорусским обществом стоит задача внимательной оценки духовных поисков молодежи, предоставление возможности адекватного религиозного становления на основе духовного опыта исторически традиционных религий. Многие христианские церкви и конфессии стремятся расширить свое влияние на молодежь. Актуальной задачей белорусского общества является сохранение национального культурного наследия.

Осуществление продуктивного межрелигиозного диалога имеет особенное значение для белорусского общества, одной из важных особенностей развития которых является поликонфессиональность. В культурном пространстве Беларуси представлены десятки вероисповеданий и конфессий, соединяются православные, исламские, католические, протестантские, иудейские и другие влияния. Поликонфессиональная ситуация, существующая на длительном историческом протяжении, способствовала формированию таких черт национального характера, как толерантность, открытость, гостеприимство, уравновешенность, стремление к согласию.

Проблемам межрелигиозного диалога, ведущегося на широкой международной основе, был посвящен ряд международных научных конференций, организованных руководством Республики Беларусь, Белорусской православной церковью и другими исторически традиционными конфессиями. В 1990 г. в Минске прошел Второй официальный диалог между Православными церквами и Всемирным альянсом реформатских церквей. С православной стороны в нем участвовали представители 9 автокефальных церквей. В мае 1998 г. в Минске проводились богословские собеседования представителей РПЦ и Германской епископской конференции католической церкви во главе с кардиналом Фридрихом Веттером на тему «Единство и многообразие в церкви». В 1996 г. на базе Белорусского экзархата была проведена миротворческая межконфессиональная конференция «Призваны к одной надежде в союзе мира», в которой приняли участие представители религиозных объединений стран СНГ и Балтии. В октябре 2007 г. в Минске прошла международная научная конференция «Диалог христианства и ислама в условиях глобализации», организованная Институтом религиозного диалога и межконфессиональных коммуникаций при Синоде Белорусской Православной Церкви [4]. Во вступительном слове Митрополит Минский и Слуцкий Филарет сказал: «Всем членам мирового сообщества следует учиться веротерпимо жить друг рядом с другом, культурно обогащать друг друга в процессе религиозного диалога, не отказываясь при этом от собственной религии и связанных с ней убеждений и нравов, правил и условий, традиций и требований». По мнению митрополита Филарета, диалог как форма общения, исключает столкновение или противостояние христианской и исламской цивилизаций. Участникам диалога следует избегать негативных последствий, связанных с размыванием границ культурной и религиозной идентичности, ведущего к разжиганию конфликтов, росту нетерпимости, развитию представления о собственной исключительности. Межрелигиозный диалог является незаменимым средством преодоления религиозной, политической и социальной конфронтации. По-настоящему он осуществляется при проявлении взаимного уважения и сохранения верности собственной традиции.

В ноябре 2009 г. в Минске проходила международная конференция религиозных деятелей «Диалог иудаизма и христианства», приуроченная к Дню борьбы против фашизма, апартеида, антисемитизма, в которой приняли участие представители православной, католической, протестантской, мусульманской и иудейской традиций.

Ярким примером сотрудничества белорусских и российских религиозных структур являются совместно проводимые общественные мероприятия, симпозиумы, семинары. Активно реализуются разнообразные культурнообразовательные программы, знакомящие общественность Беларуси, России и других стран с ценностями религиозного искусства. Заметным событием в развитии межрелигиозного и межкультурного сотрудничества стала выставка «Православная икона России, Украины, Беларуси», приуроченная к 1020-летию 
крещения Руси. В экспозиции были представлены 88 произведений XIV-XIX веков из собраний Государственной Третьяковской галереи, Национального Киево-Печерского историко-культурного заповедника (Киев), Национального художественного музея Республики Беларусь. В плане обмена культурными ценностями необходимо отметить мероприятия, направленные на активное участие молодежной аудитории. Так в августе 2009 г. представители Беларуси, России и Украины приняли участие в VI православном фестивале «Одигитрия» в г. Витебск. Программа фестиваля включала лекции и семинары на духовные темы, спортивные и интеллектуальные состязания.

В современной Беларуси, как во всех странах мира, религия является одной из влиятельных форм мировоззрения и важной областью культуры. К актуальным тенденциям духовной жизни современного общества можно отнести усложнение и динамику религиозной жизни. «В настоящее время, когда взрослеет очередное поколение, выросшее в условиях сосуществования светского и религиозного мировоззрений, когда сформировалась конфессиональная среда общества, когда установились направления и формы взаимодействия государства и религиозных организаций, можно говорить о наступлении фазы качественных изменений религиозной сферы. Одной из характеристик этих изменений можно считать неизбежный переход к более глубокому освоению людьми содержания тех религий, которые они выбирают» [3, с. 105].

Проявления религиозного фундаментализма, проповедующего стойкое неприятие современности, критику светской модели жизни, в целом не характерны для современной Беларуси. Тем не менее, фундаменталистские идеи неприятия западной модели развития, стремление опереться на традиционные ценности находят понимание у некоторой части жителей Беларуси.

Одной из важных тенденцией религиозной жизни является развитие экуменического движения, направленного на достижение взаимопонимания, консолидации, соизмерения позиций по важным проблемам современной жизни христианских церквей и конфессий. Традиционные религии и церкви стремятся дать согласованный ответ на ключевые вызовы современности. Эта тенденция отражает стремление восстановить духовную целостность, обеспечить благоприятные перспективы развития, преодолеть противоречия в от- ношениях с окружающим миром. Необходимо отметить, что ряд иерархов Белорусской православной церкви, отметим особенно важную роль деятельности митрополита Минского и Слуцкого Филарета, выступили в качестве организаторов широких межконфессиональных контактов и разнообразных форм сотрудничества религий и церквей.

Сегодня существует определенный интерес к эзотерике, мистике, оккультным учениям и практикам. Ряд учений этого плана имеют некоторое влияние на представителей современной белорусской интеллигенции.

Сложности адаптации традиционных религий к тенденциям глобализации способствовали появлению новых религиозных движений. Новые движения, секты, мистические, сатанинские и неоязыческие сообщества начинают составлять все более серьезную конкуренцию традиционным религиям и церквям. Вместе с тем, следует отметить, что в современных исследованиях не отмечается значительный интерес жителей Беларуси к деятельности новых религиозных движений. Это касается и молодежной аудитории.

Одной из важных тенденций трансформации современного общественного сознания является мировоззренческий плюрализм. Возникают сложности адаптации религиозных традиций к процессам активного продвижения светского общества, провозглашающего ценности толерантности и гуманизма. В культурном пространстве современной Беларуси проявляются тенденции нового секуляризма, который рассматривается как предпосылка толерантного сосуществования различных культур. Заметными становятся проявления гражданского, этического и светского космополитизма, в рамках которого вопрос о путях достижения духовно-религиозной идентичности рассматривается как личное дело. Достаточно характерным для жителей Беларуси становится стремление верить, не будучи вовлеченным в институциональное вероисповедание.

\section{Список литературы}

1.Республика Беларусь в зеркале социологии. Сборник материалов социологических исследований за 2011 год. Минск, 2012. 105 с.

2.Карасёва, С. Г. Некоторые особенности религиозного населения Беларуси (по материалам исследования «Типология религиозности в современной Беларуси», 2012-2015 гг.) / С. Г. Карасёва [и др.] // Философия и социальные науки. 2016. № 1. C. $82-91$.

3.Карасёва, С. Г. Характеристики вовлеченности населения Беларуси в религию: мировоззрен- 
ческий аспект / С. Г. Карасёва, Е.В.Шкурова, С. И. Шатравский // Вестник Православного Свято-Тихоновского гуманитарного университета. Серия I: Богословие. Философия. Религиоведение. 2017. Вып. 70. С. 85-109.
4. Владыка Филарет на международной конференции в Минске призвал мировое сообщество учиться веротерпимости. URL: https://naviny.by/ rubrics/society/2007/10/26/ic_news_116_279350 (25.03.18).

Viktor R. Iazykovich, Ph. D. in Philosophy. Associate Professo,r Belarusian State University of Culture and Arts (Minsk, Belarus) yazykovich55@mail.ru

\title{
TRADITIONAL RELIGIONS AND CHURCHES IN MODERN BELARUS: LEVEL OF INFLUENCE, AREAS OF ACTIVITIES
}

\begin{abstract}
The article gives the key results of several sociological researches undertook to clear confessional situation in the today's Belarus Republic. Data about a level of Belarussian citizens' involvement into active religious life is outlined. A set of the most powerful religious organizations of the state is named (the leader here is the Belorussian Orthodox Church, exarchate of the Russian Orthodox Church). The main areas of activities of Belarussian religious organizations, such as enlightenment, informational and cultural work, are reviewed; the paper counts major religious projects and measures in education, science, fine art, music, and other spheres. Also, the author stresses out a leading role of the Orthodoxy in construction of moral consciousness, culture and art of Belorussia's people.

Keywords: Belorussian Orthodox Church, Russian Orthodox Church, a language of liturgy, enlightenment, cultural activities, Orthodox culture, a religious identity, Orthodoxy, Catholicism, Islam, Judaism, inter-religious dialogue.

\section{References}

1. Respublika Belarus' $\mathrm{v}$ zerkale sociologii. Sbornik materialov sociologicheskih issledovanij za 2011 god [Republic of Belarus in a Mirror of Sociology. Collection of Writings of Sociological Researches for 2011]. Minsk, 2012. 105 p. [In Russ.].

2. Karasyova, S. G., Shkurova E. V., Shatravskij S. I., Domanskaya A. I., Kazmiruk M. V. Nekotorye oso-bennosti religioznogo naseleniya Belarusi (po materialam issledovaniya «Tipologiya religioznosti $\mathrm{v}$ sovre-mennoj Belarusi», 2012-2015 gg.). [Some Peculiarities of Religious Belorussia's Population (Materials of Research "Typology of Religiousness in the Modern Belorussia", 2012-2015)] // Filosofiya i social'nye

nauki [Philosophy and Social Sciences]. 2016. No. 1. Pp. 82-91. [In Russ.].

3. Karasyova, S. G. Harakteristiki vovlechennosti naseleniya Belarusi v religiyu: mirovozzrencheskij aspekt [Involvement of Belorussia's Population into a Religion: A Worldview Aspect] / S. G. Karasyova, E. V. Shkurova, S. I. Shatravskij // Vestnik Pravoslavnogo Svyato-Tihonovskogo gumanitarnogo universiteta. Seriya I: Bogoslovie. Filosofiya. Religiovedenie.

4. His Grace Filaret Called the World Community to Learn to Religious Tolerance at International Conference in Minsk. URL: https://naviny.by/rubrics/ society/2007/10/26/ic_news_116_279350 (25.03.18). [In Russ.].
\end{abstract}

УДК 130/2(4/5):23/28:304.444

DOI: $10.32340 / 2514-772 X-2019-1-49-57$

О. В. Попова, доктор педагогических наук, профессор, Алтайский государственный гуманитарно-педагогический университет им. В. М. Шукшина (Бийск, Россия) pov@bigpi.biysk.ru

Д. В. Попов, Библиотека информационных образовательных ресурсов «Умней» (Москва, Россия) denissga2015@yandex.ru

\section{ВЗАИМОСВЯЗЬ ЕВРАЗИЙСТВА И ХРИСТИАНСТВА КАК МОДЕЛЬ СОЦИАЛЬНО СПРАВЕДЛИВОГО ОБЩЕСТВА}

Аннотация. Рассмотрена возможность построения социально справедливого общества для современной многонациональной России, в качестве идейного основания которого авторы предлагают рассматривать синтез фундаментальных положений христианского вероучения и взглядов представителей идейно-философского и общественно-политического течения евразийства. Предложена автор- 